UDC 629.015:625.72

G. G. Pivnyak ${ }^{1}$, Academ. of NAS of Ukraine, Dr. Sc. (Tech.), Prof., orcid.org/0000-0002-8462-2995, V.P.Sakhno ${ }^{2}$, Dr. Sc. (Tech.), Prof., orcid.org/0000-0002-5144-7131, V.V. Kravets ${ }^{1}$, Dr. Sc. (Tech.), Prof., orcid.org/0000-0003-4770-0269,

K. M. Bas ${ }^{1,2}$, Cand. Sc. (Tech.), Assoc. Prof., orcid.org/0000-0003-2918-3501
DOI: $10.29202 /$ nvngu/2019-1/8

1 - Dnipro University of Technology, Dnipro, Ukraine, e-mail: prof.w.kravets@gmail.com

2 - National Transport University, Kyiv, Ukraine, e-mail: k.m.bas.69@gmail.com

\title{
METHOD FOR DETERMINING HIGH-SPEED VEHICLE CONTACT FORCES OF THE GROUND TRANSPORT
}

Purpose. Reliability and engineering precision improvement of 3D-modelling for kinematics and dynamics of ground transport vehicles. Criteria development for results verification.

Methodology. Equivalent motive force of a high-speed vehicle of ground transport is determined based on program hodograph corresponding to spiral-screw trajectory. Motive force distribution is carried out for two supporting points of a ground transport vehicle. The problem is solved based on Varignon's theorem in a vector format, and it is considered in moving frame of reference of true trajectory trihedral. The formulated statistically undetermined problem is solved by involving design variable considering reactivity or inactivity of the supporting point. The verification of obtained analytical solution is carried out on the basis of kinetostatic invariants.

Findings. The formulae are suggested for determining analytic contact forces in programmed motion of a highspeed vehicle of ground transport for tandem and parallel flow diagram of supporting points with respect to their reactivity or inactivity. The obtained formulae for contact forces comply with the first static invariant for the problem considered. The second static invariant enables determination of analytic dependences between the components of unknown contact forces, equivalent motive force, and geometric parameters.

Originality. A method is suggested for statistically undetermined problem solution of equivalent motive force distribution for two contact points of a ground transport vehicle and the supportive surface. The method is based on the classical results of mechanics use: Varignon's theorem, static invariants, true trajectory trihedral of a ground transport vehicle. The formulated problem becomes resolvable in corpora by means of involving technically reasonable hypothesis of reactive-inactive links at the supporting point.

Practical value. The obtained analytical solutions of formulated problem are informational, clear and convenient for analysis in engineering practice of dynamic development of high-speed ground transport vehicles. The calculation formulae are provided as properly arranged and adapted for machine-assisted realization. The method enables widening of resolvable problems range for dynamic development of ground transport vehicles of complex flow diagrams and any quantity of supporting points.

Keywords: hodograph, true trihedral, Varignon's theorem, static invariants, contact forces, ground transport vehicle

Introduction. General problems of determining constraint forces in mechanical systems with two or more supporting points belong to statistically undetermined ones $[1,2]$. High-speed vehicles of ground transport moving under specified schedule on the determined supporting surface are considered as such mechanical systems $[3,4]$. Constraint forces occurring in the contact points of ground transport vehicles and supporting surface enable control and stability of motion [5]. Therefore, the improvement of methods for determining contact motive forces of ground transport vehicles, as well as improvement of results reliability and engineering precision for dynamic process simulation is considered as an urgent problem.

Analysis of the recent research and publications. Such studies of dynamic systems are carried out based on innovative approaches to problem formulation and new methods of mathematical description and simulation of

(C) Pivnyak G. G., Sakhno V.P., Kravets V.V., Bas K. M., 2019 dynamic processes $[6,7]$. The following problems are considered: dynamics of the road-tyre-automobiledriver system, stability of wheelset motion of transport machines, influence assessment of centrifugal, Coriolis, gyroscopic, and tangential inertial forces on the dynamic loading of high-speed vehicles of ground transport and impact on road surface [4]. The studies in such fields belong to the type of tasks of technical systems dynamic design to be solved on the base of complex approach with application of both computing and fullscale experiment [8].

Unsolved aspects of the problem. The resulting motive force determined earlier and providing the determined motion of a high-speed vehicle of ground transport along the spiral-screw trajectory with respect to gravitation force and inertial and aerodynamic forces is to be distributed equivalently over the contact points with supportive surface. As for the single contact point, the solution is simplistic. In case of two or more contact points the problem is considered to be a statistically un- 
determined one and requires supplementary conditions compliant with its initial formulation. The main part of the problem under consideration is determined by reliability substantiation of the method suggested for evaluation of indeterminate forms in the problem of equivalent distribution of motive force over the two contact points of the vehicle and supportive surface.

The objectives of the article. To provide the solution method for statistically undetermined problem for equivalent distribution of resulting motive force over the two contact points of the ground transport high-speed vehicle and supportive surface, to substantiate the reliability of the obtained results.

Methods description. Equivalent motive force is distributed over two contact points. The problem is discussed in moving frame of reference (true trihedral frame), where the resulting motive force $\left(N_{c}, N_{n}, N_{b}\right)$ is considered to be determined by means of the program hodograph of automobile carrying over a distance. The contact point arrangement is set in the true trihedral frame (osculating plane), it is shown in Fig. 1.

The $\left(\bar{F}_{1}, \bar{F}_{2}\right)$, system of static equivalent forces applied in two contact points is determined. The two possible arrangement frames for $\left(O_{1}, O_{2}\right)$ supportive points are considered for ground transport vehicles as follows:

- tandem;

- parallel,

where $\bar{\tau}$ stands for motion direction.

Presentation of the main research. The formulated statistic problem is solved based on Varignon's theorem

$$
\overline{r_{1}} \times \bar{F}_{1}+\bar{r}_{2} \times \bar{F}_{2}=\bar{r} \times \bar{N}
$$

Herein:

- for the tandem frame

$$
\overline{r_{1}}=\bar{r}+\bar{\tau} l_{1} ; \quad \overline{r_{2}}=\bar{r}-\bar{\tau} l_{2} ;
$$

- for the parallel frame

$$
\overline{r_{1}}=\bar{r}+\bar{n} h_{1} ; \quad \overline{r_{2}}=\bar{r}-\bar{\tau} l_{2} .
$$

The geometric parameters $l_{1}, l_{2}, h_{1}, h_{2}$ are set in the system of coordinates, connected with the transport ve- hicle: $l_{1}, h_{1}$ stand for distance between point mass $M$ and first supporting point $O_{1} ; l_{2}, h_{2}$ stand for distance between point mass $M$ and second supporting point $O_{2}$.

In particular, combining $O$ pole with the second supporting point $\mathrm{O}_{2}$ we obtain:

- for the tandem frame

$$
\bar{r}=\bar{\tau} l_{2} ; \quad \bar{r}_{2}=0 ; \quad \overline{r_{1}}=\left(l_{1}+l_{2}\right) \bar{\tau} ;
$$

- for the parallel frame

$$
\bar{r}=\bar{n} h_{2} ; \quad \bar{r}_{2}=0 ; \quad \overline{r_{1}}=\left(h_{1}+h_{2}\right) \bar{n} .
$$

In such a case, Varignon's theorem is represented as a true trihedral frame in the form of the determinants as follows:

- for the tandem frame

$$
\left|\begin{array}{ccc}
\bar{\tau} & \bar{n} & \bar{b} \\
l_{1}+l_{2} & 0 & 0 \\
F_{1 \tau}^{T} & F_{1 n}^{T} & F_{1 b}^{T}
\end{array}\right|=\left|\begin{array}{ccc}
\bar{\tau} & \bar{n} & \bar{b} \\
l_{2} & 0 & 0 \\
N_{\tau} & N_{n} & N_{b}
\end{array}\right| ;
$$

- for the parallel frame

$$
\left|\begin{array}{ccc}
\bar{\tau} & \bar{n} & \bar{b} \\
0 & h_{1}+h_{2} & 0 \\
F_{1 \tau}^{\Pi} & F_{1 n}^{\Pi} & F_{1 b}^{\Pi}
\end{array}\right|=\left|\begin{array}{ccc}
\bar{\tau} & \bar{n} & \bar{b} \\
0 & h_{2} & 0 \\
N_{\tau} & N_{n} & N_{b}
\end{array}\right| .
$$

Whence it follows:

- for the tandem frame

$$
F_{1 \tau}^{T} \text { is underdetermined; } F_{1 n}^{T}=\frac{l_{2}}{l_{1}+l_{2}} N_{n} ;
$$

$$
F_{1 b}^{T}=\frac{l_{2}}{l_{1}+l_{2}} N_{b} ;
$$

- for the parallel frame

$$
\begin{gathered}
F_{1 \tau}^{\Pi}=\frac{h_{2}}{h_{1}+h_{2}} N_{\tau} ; F_{1 n}^{\Pi} \text { is underdetermined; } \\
F_{1 b}^{\Pi}=\frac{h_{2}}{h_{1}+h_{2}} N_{b} .
\end{gathered}
$$

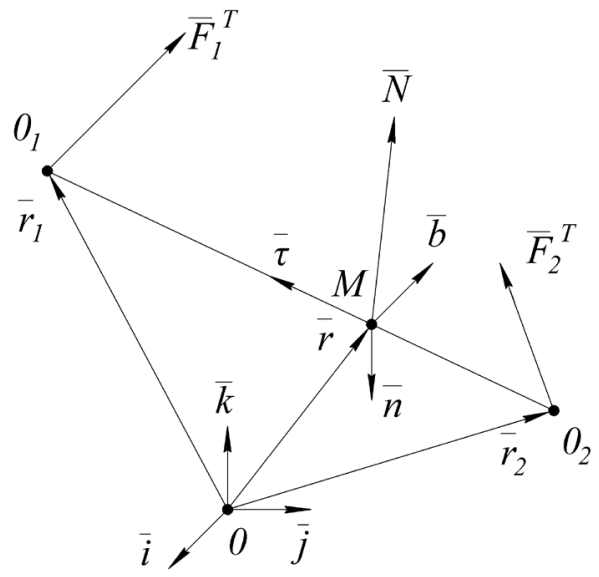

$a$

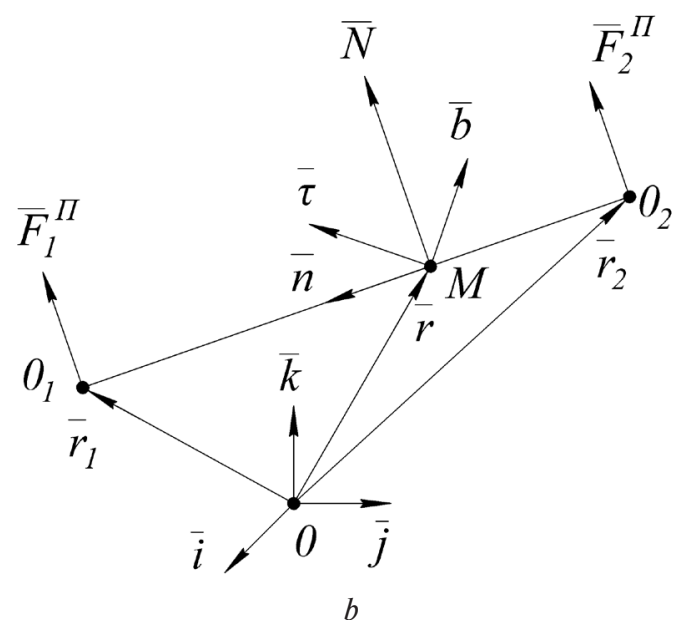

Fig. 1. Flow diagram of a transport vehicle with two contact points:

$a$-tandem; $b$ - parallel 
Combining $O$ pole with the first supporting point $O_{1}$ we obtain:

- for the tandem frame

$$
\bar{r}=-l_{1} \bar{\tau} ; \quad \overline{r_{1}}=0 ; \quad \overline{r_{2}}=-\left(l_{1}+l_{2}\right) \bar{\tau} ;
$$

- for the parallel frame

$$
\bar{r}=-h_{1} \bar{n} ; \quad \bar{r}_{1}=0 ; \quad \bar{r}_{2}=-\left(h_{1}+h_{2}\right) \bar{n} .
$$

Herein Varignon's theorem as a true trihedral frame is represented as:

- for the tandem frame

$$
\left|\begin{array}{ccc}
\bar{\tau} & \bar{n} & \bar{b} \\
l_{1}+l_{2} & 0 & 0 \\
F_{2 \tau}^{T} & F_{2 n}^{T} & F_{2 b}^{T}
\end{array}\right|=\left|\begin{array}{ccc}
\bar{\tau} & \bar{n} & \bar{b} \\
l_{1} & 0 & 0 \\
N_{\tau} & N_{n} & N_{b}
\end{array}\right|
$$

- for the parallel frame

$$
\left|\begin{array}{ccc}
\bar{\tau} & \bar{n} & \bar{b} \\
0 & h_{1}+h_{2} & 0 \\
F_{2 \tau}^{\ddot{I}} & F_{2 n}^{\ddot{I}} & F_{2 b}^{\ddot{I}}
\end{array}\right|=\left|\begin{array}{ccc}
\bar{\tau} & \bar{n} & \bar{b} \\
0 & h_{1} & 0 \\
N_{\tau} & N_{n} & N_{b}
\end{array}\right|,
$$

whence it follows:

- for the tandem frame

$$
\begin{gathered}
F_{2 \tau}^{T} \text { is underdetermined; } F_{2 n}^{T}=\frac{l_{1}}{l_{1}+l_{2}} N_{n} ; \\
F_{2 b}^{T}=\frac{l_{1}}{l_{1}+l_{2}} N_{b} ;
\end{gathered}
$$

- for the parallel frame

$$
\begin{gathered}
F_{2 \tau}^{\Pi}=\frac{h_{1}}{h_{1}+h_{2}} N_{\tau} ; F_{2 n}^{\Pi} \text { is underdetermined; } \\
F_{2 b}^{\Pi}=\frac{h_{1}}{h_{1}+h_{2}} N_{b} .
\end{gathered}
$$

Statistic invariants in the problem of contact forces determination. The first and second statistic invariants serve as a means of obtained results verification and provide the additional information for solving the statistically undetermined problem under consideration.

1. First statistic invariant. The first statistic invariant of this problem is represented in the following vectorial form

$$
\bar{F}_{1}+\bar{F}_{2}=\bar{N}
$$

For the tandem frame in the normal plane of true trihedral the first statistic invariant has the following coordinate representation

$$
F_{1 n}^{T}+F_{2 n}^{T}=N_{n} ; \quad F_{1 b}^{T}+F_{2 b}^{T}=N_{b},
$$

or in expanded form using the obtained results

$$
\begin{aligned}
& \frac{l_{1}}{l_{1}+l_{2}} N_{n}+\frac{l_{2}}{l_{1}+l_{2}} N_{n}=N_{n} ; \\
& \frac{l_{1}}{l_{1}+l_{2}} N_{b}+\frac{l_{2}}{l_{1}+l_{2}} N_{b}=N_{b},
\end{aligned}
$$

i. e. the abovementioned conditions are identically satisfied for the solutions obtained.

The projection of the tangential basis vector

$$
F_{1 \tau}^{T}+F_{2 \tau}^{T}=N_{\tau}
$$

contains uncertainty. To provide evaluation of indeterminate forms the following technically substantiated conditions are introduced:

- the first and second contact points are reactive (driving) i.e.

$$
F_{1 \tau}^{T}>0 ; \quad F_{2 \tau}^{T}>0
$$

Then the design parameter $k$ is introduced for all wheel drive transport vehicle

$$
k=\left|\frac{F_{1 \tau}^{T}}{F_{2 \tau}^{T}}\right| .
$$

Considering the given design parameter $k$, we obtain

$$
F_{1 \tau}^{T}=k F_{2 \tau}^{T},
$$

whence it follows

$$
k F_{2 \tau}^{T}+F_{2 \tau}^{T}=N_{\tau}
$$

that is

$$
F_{2 \tau}^{T}=\frac{1}{1+k} N_{\tau} ; \quad F_{1 \tau}^{T}=\frac{k}{1+k} N_{\tau}
$$

In case of equal motive forces at the contact points $\left(F_{1 \tau}^{T}=F_{2 \tau}^{T}\right)$ the design parameter $k=1$ and accordingly

$$
F_{2 \tau}^{T}=\frac{1}{2} N_{\tau} ; \quad F_{1 \tau}^{T}=\frac{1}{2} N_{\tau}
$$

Therefore, the first statistic invariant in the projection of tangential on the basis vector for the solution suggested is also satisfied identically

$$
\frac{k}{1+k} N_{\tau}+\frac{1}{1+k} N_{\tau}=N_{\tau}
$$

The following technically realized design frame is considered:

- the first contact point is reactive (driving)

$$
F_{1 \tau}^{T}>0
$$

- the second contact point is inactive (driven)

$$
F_{2 \tau}^{T}<0 \text {. }
$$

Design parameter $k$ for a front wheel drive transport vehicle is determined as

$$
k=\left|\frac{F_{1 \tau}^{T}}{F_{2 \tau}^{T}}\right| .
$$

In the case, the technically substantiated condition is $k>1$, i. e. the motive force exceeds the resistant force at the contact points $\left(F_{1 \tau}^{T}>F_{2 \tau}^{T}\right)$. Therefore, the first statistic invariant in the projection of tangential on the basis vector for true trihedral is expressed as 


$$
F_{1 \tau}^{T}-F_{2 \tau}^{T}=N_{\tau}
$$

where

$$
F_{1 \tau}^{T}=k F_{2 \tau}^{T}
$$

or

$$
k F_{2 \tau}^{T}-F_{2 \tau}^{T}=N_{\tau}
$$

i.e.

$$
F_{2 \tau}^{T}=\frac{1}{k-1} N_{\tau} ; \quad F_{1 \tau}^{T}=\frac{k}{k-1} N_{\tau}
$$

In case of a rear-wheel drive transport vehicle we suggest that:

- the first contact point is inactive (driven)

$$
F_{1 \tau}^{T}<0
$$

- the second contact point is reactive (driving)

$$
F_{2 \tau}^{T}>0 \text {. }
$$

Since automobile motive force exceeds the resistant force at the contact points $\left(F_{1 \tau}^{T}<F_{2 \tau}^{T}\right)$, then $k<1$ and also

$$
-F_{1 \tau}^{T}+F_{2 \tau}^{T}=N_{\tau}
$$

or

$$
-k F_{2 \tau}^{T}+F_{2 \tau}^{T}=N_{\tau}
$$

i.e.

$$
F_{2 \tau}^{T}=\frac{1}{1-k} N_{\tau} ; \quad F_{1 \tau}^{T}=\frac{k}{1-k} N_{\tau}
$$

In case of parallel arrangement of contact points the first statistic invariant in the projections on the basis vectors for true trihedral is expressed as

$$
F_{1 \tau}^{\Pi}+F_{2 \tau}^{\Pi}=N_{\tau} ; \quad F_{1 b}^{\Pi}+F_{2 b}^{\Pi}=N_{b} ; \quad F_{1 n}^{\Pi}+F_{2 n}^{\Pi}=N_{n} .
$$

Here the solutions obtained in the projections of tangential and binormal on the basis vectors are satisfied equally

$$
\begin{aligned}
& \frac{h_{1}}{h_{1}+h_{2}} N_{\tau}+\frac{h_{2}}{h_{1}+h_{2}} N_{\tau}=N_{\tau} ; \\
& \frac{h_{1}}{h_{1}+h_{2}} N_{b}+\frac{h_{2}}{h_{1}+h_{2}} N_{b}=N_{b},
\end{aligned}
$$

and in order to provide evaluation of indeterminate forms in the projections on unit normal vector, the following technically substantiated conditions are introduced

$$
F_{1 n}^{\Pi}>0 ; \quad F_{2 n}^{\Pi}>0
$$

or

$$
F_{1 n}^{\Pi}<0 ; \quad F_{2 n}^{\Pi}<0 .
$$

Moreover, the design parameter

$$
\mu=\left|\frac{F_{1 \tau}^{\Pi}}{F_{2 \tau}^{\Pi}}\right|,
$$

is considered as a given one.
Then

$$
F_{1 n}^{\Pi}=\mu F_{2 n}^{\Pi} .
$$

Wherefrom,

$$
\mu F_{2 n}^{\Pi}+F_{2 n}^{\Pi}=N_{n} .
$$

Consequently,

$$
F_{2 n}^{\Pi}=\frac{1}{1+\mu} N_{n} ; \quad F_{1 n}^{\Pi}=\frac{\mu}{1+\mu} N_{n} .
$$

In particular, for a symmetric parallel frame it is given that

$$
F_{1 n}^{\Pi}=F_{2 n}^{\Pi},
$$

i.e.

$$
\mu=1 .
$$

Then we obtain the evident result

$$
F_{2 n}^{\Pi}=\frac{1}{2} N_{n} ; \quad F_{1 n}^{\Pi}=\frac{1}{2} N_{n} .
$$

Therefore, for the parallel frame of the contact points arrangement the first statistic invariant in projection on unit normal vector is also satisfied equally to the suggested solution

$$
\frac{\mu}{1+\mu} N_{n}+\frac{1}{1+\mu} N_{n}=N_{n} .
$$

2. Second statistic invariant. The second statistic invariant of this problem is represented in the following vectorial form

$$
\bar{N} \cdot\left(\overline{r_{1}} \times F_{1}\right)+\bar{N} \cdot\left(\overline{r_{2}} \times F_{2}\right)=\bar{N} \cdot(\bar{r} \times \bar{N}),
$$

or

$$
\bar{N} \cdot\left(\overline{r_{1}} \times F_{1}\right)+\bar{N} \cdot\left(\overline{r_{2}} \times F_{2}\right)=0,
$$

as

$$
\bar{N} \cdot(\bar{r} \times \bar{N})=0 .
$$

In particular, for tandem frame combining $O$ pole with second supporting point $\mathrm{O}_{2}$ we obtain

$$
\overline{r_{2}}=0 ; \quad \overline{r_{1}}=\left(l_{1}+l_{2}\right) \bar{\tau},
$$

i.e.

$$
\bar{N} \cdot\left(\bar{\tau} \times \overline{F_{1}}\right)=0,
$$

since

or

$$
l_{1}+l_{2} \neq 0
$$

$$
\overline{F_{1}} \cdot(\bar{N} \times \bar{\tau})=0 .
$$

In the frame of true trihedral we are to note

$$
\left|\begin{array}{ccc}
F_{1 \tau} & F_{1 n} & F_{1 b} \\
N_{\tau} & N_{n} & N_{b} \\
1 & 0 & 0
\end{array}\right|=0,
$$

or

$$
\left|\begin{array}{ll}
F_{1 n} & F_{1 b} \\
N_{n} & N_{b}
\end{array}\right|=0
$$


i.e.

$$
\frac{F_{1 n}}{F_{1 b}}=\frac{N_{n}}{N_{b}} .
$$

Combining 0 pole with the first supporting point $O_{1}$ we obtain

$$
\overline{r_{1}}=0 ; \quad \bar{r}_{2}=-\left(l_{1}+l_{2}\right) \bar{\tau}
$$

i.e.

$$
\bar{N} \cdot\left(\bar{\tau} \times \bar{F}_{2}\right)=0
$$

or

$$
\bar{F}_{2} \cdot(\bar{N} \times \bar{\tau})=0
$$

Wherefrom,

$$
\left|\begin{array}{ccc}
F_{2 \tau} & F_{2 n} & F_{2 b} \\
N_{\tau} & N_{n} & N_{b} \\
1 & 0 & 0
\end{array}\right|=0
$$

or

$$
\left|\begin{array}{cc}
F_{2 n} & F_{2 b} \\
N_{n} & N_{b}
\end{array}\right|=0
$$

i.e.

$$
\frac{F_{2 n}}{F_{2 b}}=\frac{N_{n}}{N_{b}} .
$$

Therefore,

$$
\frac{F_{1 n}}{F_{1 b}}=\frac{F_{2 n}}{F_{2 b}}=\frac{N_{n}}{N_{b}} .
$$

Combining 0 pole with $M$ point we obtain

$$
\overline{r_{1}}=l_{1} \bar{\tau} ; \quad \overline{r_{2}}=-l_{2} \bar{\tau},
$$

i.e.

or

$$
l_{1} \bar{N} \cdot\left(\bar{\tau} \times \bar{F}_{1}\right)-l_{2} \bar{N} \cdot\left(\bar{\tau} \times \bar{F}_{2}\right)=0
$$

$$
l_{1} \bar{F}_{1} \cdot(\bar{N} \times \bar{\tau})=l_{2} \bar{F}_{2} \cdot(\bar{N} \times \bar{\tau})
$$

and further,

$$
l_{1}\left|\begin{array}{ccc}
F_{1 \tau} & F_{1 n} & F_{1 b} \\
N_{\tau} & N_{n} & N_{b} \\
1 & 0 & 0
\end{array}\right|=l_{2}\left|\begin{array}{ccc}
F_{2 \tau} & F_{2 n} & F_{2 b} \\
N_{\tau} & N_{n} & N_{b} \\
1 & 0 & 0
\end{array}\right|,
$$

or

$$
l_{1}\left|\begin{array}{ll}
F_{1 n} & F_{1 b} \\
N_{n} & N_{b}
\end{array}\right|=l_{2}\left|\begin{array}{cc}
F_{2 n} & F_{2 b} \\
N_{n} & N_{b}
\end{array}\right|,
$$

whence it follows

$$
\frac{F_{1 n} N_{b}-F_{1 b} N_{n}}{F_{2 n} N_{b}-F_{2 b} N_{n}}=\frac{l_{2}}{l_{1}},
$$

and also

$$
\frac{F_{1 n} l_{1}-F_{2 b} l_{2}}{F_{1 n} l_{1}-F_{2 b} l_{2}}=\frac{N_{n}}{N_{b}}
$$

In case of the parallel framework combining 0 pole and the second supportive point $\mathrm{O}_{2}$, the first supportive point $O_{1}$, and $M$ point, we obtain respectively:

$$
\begin{aligned}
& \text { 1. } \bar{r}_{2}=0 ; \quad \bar{r}_{1}=\left(h_{1}+h_{2}\right) \bar{n} ; \quad \overline{F_{1}} \cdot(\bar{N} \times \bar{n})=0 ; \\
& \left|\begin{array}{ccc}
F_{1 \tau} & F_{1 n} & F_{1 b} \\
N_{\tau} & N_{n} & N_{b} \\
0 & 1 & 0
\end{array}\right|=0 ; \quad\left|\begin{array}{cc}
F_{1 \tau} & F_{1 b} \\
N_{\tau} & N_{b}
\end{array}\right|=0 ; \quad \frac{F_{1 \psi}}{F_{1 b}}=\frac{N_{\tau}}{N_{b}} . \\
& \text { 2. } \bar{r}_{1}=0 ; \quad \bar{r}_{2}=-\left(h_{1}+h_{2}\right) \bar{n} ; \quad \overline{F_{2}} \cdot(\bar{N} \times \bar{n})=0 ;
\end{aligned}
$$$$
\left|\begin{array}{ccc}
F_{2 \tau} & F_{2 n} & F_{2 b} \\
N_{\tau} & N_{n} & N_{b} \\
0 & 1 & 0
\end{array}\right|=0 ; \quad\left|\begin{array}{cc}
F_{2 \tau} & F_{2 b} \\
N_{\tau} & N_{b}
\end{array}\right|=0 ; \quad \frac{F_{2 \psi}}{F_{2 b}}=\frac{N_{\tau}}{N_{b}} \text {. }
$$

Therefore,

$$
\frac{F_{1 n}}{F_{1 b}}=\frac{F_{2 \tau}}{F_{2 b}}=\frac{N_{n}}{N_{b}} .
$$

3. $\bar{r}_{1}=h_{1} \bar{n} ; \quad \bar{r}_{2}=-h_{2} \bar{n} ; \quad h_{1} \overline{F_{1}} \cdot(\bar{N} \times \bar{n})=h_{2} \bar{F}_{2} \cdot(\bar{N} \times \bar{n})$;

$$
\begin{aligned}
& h_{1}\left|\begin{array}{ccc}
F_{1 \tau} & F_{1 n} & F_{1 b} \\
N_{\tau} & N_{n} & N_{b} \\
0 & 1 & 0
\end{array}\right|=h_{2}\left|\begin{array}{ccc}
F_{2 \tau} & F_{2 n} & F_{2 b} \\
N_{\tau} & N_{n} & N_{b} \\
0 & 1 & 0
\end{array}\right| ; \\
& h_{1}\left|\begin{array}{cc}
F_{2 \tau} & F_{1 b} \\
N_{\tau} & N_{b}
\end{array}\right|=h_{2}\left|\begin{array}{cc}
F_{2 \tau} & F_{2 b} \\
N_{\tau} & N_{b}
\end{array}\right| ; \\
& \frac{F_{1 \tau} N_{b}-F_{1 b} N_{\tau}}{F_{2 \tau} N_{b}-F_{2 b} N_{\tau}}=\frac{h_{2}}{h_{1}} ; \quad \frac{F_{1 \tau} h_{1}-F_{2 \tau} h_{2}}{F_{1 b} h_{1}-F_{2 b} h}=\frac{N_{\tau}}{N_{b}} .
\end{aligned}
$$

Conclusions. The method was developed for equivalent distribution of resulting motive force over two contact points of a ground transport vehicle and supportive surface for program motion according to spiral-screw trajectory. The statistically undetermined problem was completely solved analytically by means of involving technically reasonable hypothesis of reactive-inactive links at contact points for tandem and parallel frames of a ground transport vehicle. The verification of solution obtained was carried out according to the first kinetostatic invariant. Based on the second kinetostatic invariant the analytical dependences were determined linking the components of contact forces, resulting motive force and geometric parameters of flow diagrams for a ground transport vehicle in terms of frame of true trajectory trihedral. The obtained analytical solutions are informational, clear and convenient for application in engineering practice of dynamic development of high-speed ground transport vehicles. The method suggested enables consistent generalizations in case of increasing quantity of supporting points and complications of vehicle flow diagrams.

\section{References.}

1. Kolosov, D., Bilous, O., Tantsura, H. and Onyshchenko, S., 2018. Stress-strain state of a flat tractivebearing element of a lifting and transporting machine at operational changes of its parameters. Solid State Phenomena, 277, pp. 188-201. 
2. Kyrychenko, Y., Samusia, V., Kyrychenko, V. and Goman, O., 2012. Experimental investigation of aeroelastic and hydroelastic instability parameters of a marine pipeline. Geomechanical Processes During Underground Mining, pp. 163-167. DOI: 10.5829/idosi.mejsr.2013.18.4.12426.

3. Qian (Chayn) Suna, Jianhong (Cecilia) Xiaa, Jonathan Fosterb, Torbjorn Falkmerc and Hoe Lee, 2016. Pursuing Precise Vehicle Movement Trajectory in Urban Residential Area Using Multi-GNSS RTK Tracking. In: World Conference on Transport Research - WCTR Shanghai, Published by Elsevier B.V. Science Direct, Transportation Research Procedia, 25, pp. 2356-2372. DOI: 10.1016/j.trpro.2017.05.255.

4. Kravets, V., Sakhno, V., Bas, K. and Kravets, V., 2018. Program spatial movement of high-speed vehicles. In: IOP Conf. Ser.: Mater. Sci. Eng. 383 012032. DOI: 10.1088/1757-899X/383/1/012032.

5. Protsiv, V., Ziborov, K. and Fedoriachenko, S., 2013. On formation of kinematical and dynamical parameters of output elements of the mine vehicles in transient motion. Naukovyi Visnyk Natsionalnoho Hirnychoho Universytetu, 4, pp. 64-69.

6. Strutinsky, V. and Demyanenko, A., 2016. The development of mechatronic active control system of tool spatial position of parallel kinematics machine tool. Journal of Theoretical and Applied Mechanics, 54(3), pp. 757-768. DOI: 10.15632/jtam-pl.54.3.757.

7. Taran, I.A. and Klimenko, I.Yu., 2014. Innovative Mathematical Tools for Comparative Analysis of Means of Transport Transmission. Naukovyi Visnyk Natsionalnoho Hirnychoho Universytetu, 3, pp.76-82.

8. Kravets, V.V., Bass, M., Kravets, T.V. and Tokar, L.A., 2015. Dynamic Design of Ground Transport With the Help of Computational Experiment. Mechanics, Materials Science and Engineering, October 2015. MMSE Journal Open access www.mmse.xyz, DOI: 10.13140/RG.2.1.2466.6643.

\section{Метод визначення контактних сил швидкісного екіпажу наземного транспорту}

\author{
Г. Г. Півняк ${ }^{1}$, В. П. Сахно ${ }^{2}$, В. В. Кравець ${ }^{1}$, К. М. Бас ${ }^{1,2}$ \\ 1 - Національний технічний університет „Дніпровська \\ політехніка“, м. Дніпро, Україна, e-mail: prof.w.kravets@ \\ gmail.com \\ 2 - Національний транспортний університет, м. Київ, \\ Україна, e-mail: k.m.bas.69@gmail.com
}

Мета. Підвищення достовірності та інженерної точності 3D-моделювання кінематики й динаміки екіпажів наземного транспорту. Розробка критеріїв верифікації результатів.

Методика. Еквівалентна рушійна сила швидкісного екіпажу наземного транспорту визначається за програмним годографом, що відповідає спіралегвинтовій трасі. Проводиться розподіл рушійної сили за двома опорними точками екіпажу наземного транспорту. Завдання вирішується на підставі теореми Варіньона у векторній формі й розглядається в рухомій системі відліку - натуральний трі- едр траєкторії. Поставлена статично невизначена задача вирішується шляхом уведення проектного параметра, що враховує реактивність або пасивність опорної точки. Верифікація отриманих аналітичних рішень проводиться на основі інваріантів кінетостатики.

Результати. Запропоновані формули аналітичного визначення контактних сил у програмному русі швидкісного екіпажу наземного транспорту для тандемної та паралельної структурних схем розташування опорних точок з урахуванням ознаки реактивності-пасивності. Отримані формули контактних сил задовольняють першому статичному інваріантові для даної задачі. Другий статичний інваріант дозволяє встановити аналітичні залежності між компонентами контактних сил, що визначаються еквівалентною рушійною силою та геометричними параметрами.

Наукова новизна. Запропоновано метод розв'язання статично невизначеної задачі розподілу еквівалентної рушійної сили за двома точками контакту екіпажу наземного транспорту з опорною поверхнею. Метод заснований на використанні класичних результатів механіки: теореми Варіньона, статичних інваріантів, натурального тріедру траси екіпажу наземного транспорту. Виявлено, що поставлену задачу можна розв'язати в повному обсязі шляхом уведення технічно виправданої гіпотези щодо реактивності-пасивності зв'язку в опорній точці.

Практична значимість. Отримані аналітичні розв'язки поставленої задачі інформативні, прості та зручні для аналізу в інженерній практиці динамічного проектування швидкісних екіпажів наземного транспорту. Розрахункові формули наведені в упорядкованому, компактному вигляді, безпосередньо адаптованому до комп'ютерної реалізації. Метод дозволяє розширити коло вирішуваних задач динамічного проектування екіпажів наземного транспорту складних структурних схем при довільній кількості опорних точок.

Ключові слова: годограф, натуральний тріедр, теорема Варіньона, статичні інваріанти, контактні сили, екіпаж наземного транспорту

\section{Метод определения контактных сил} скоростного экипажа наземного транспорта

Г. Г. Пивняк ${ }^{1}$, В. П. Сахно ${ }^{2}$, В. В. Кравеи,, К. М. Басс ${ }^{1,2}$ 1 - Национальный технический университет „Днепровская политехника“, г. Днепр, Украина, e-mail: prof.w.kravets@gmail.com

2 - Национальный транспортный университет, г. Киев, Украина, e-mail: k.m.bas.69@gmail.com

Цель. Повышение достоверности и инженерной точности 3D-моделирования кинематики и динамики экипажей наземного транспорта. Разработка критериев верификации результатов.

Методика. Эквивалентная движущая сила скоростного экипажа наземного транспорта определя- 
ется по программному годографу, соответствующему спирале-винтовой трассе. Проводится распределение движущей силы по двум опорным точкам экипажа наземного транспорта. Задача решается на основе теоремы Вариньона в векторной форме и рассматривается в подвижной системе отсчета натуральный триэдр траектории. Поставленная статически неопределимая задача разрешается путем введения проектного параметра, учитывающего реактивность или пассивность опорной точки. Верификация полученных аналитических решений проводится на основе инвариантов кинетостатики.

Результаты. Предложены формулы аналитического определения контактных сил в программном движении скоростного экипажа наземного транспорта для тандемной и параллельной структурных схем расположения опорных точек с учетом признака реактивности-пассивности. Полученные формулы контактных сил удовлетворяют первому статическому инварианту для рассматриваемой задачи. Второй статический инвариант позволяет установить аналитические зависимости между компонентами искомых контактных сил, эквивалентной движущей силой и геометрическими параметрами.

Научная новизна. Предложен метод решения статически неопределимой задачи распределения эквивалентной движущей силы по двум точкам контакта экипажа наземного транспорта с опорной поверхностью. Метод основан на использовании классических результатов механики: теоремы Вариньона, статических инвариантов, натурального триэдра трассы экипажа наземного транспорта. Поставленная задача оказывается разрешимой в полном объеме путем введения технически оправданной гипотезы о реактивности-пассивности связи в опорной точке.

Практическая значимость. Полученные аналитические решения поставленной задачи информативны, просты и удобны для анализа в инженерной практике динамического проектирования скоростных экипажей наземного транспорта. Расчетные формулы представлены в упорядоченном, компактном виде, непосредственно адаптированном к компьютерной реализации. Метод позволяет расширить круг решаемых задач динамического проектирования экипажей наземного транспорт сложных структурных схем при произвольном количестве опорных точек.

Ключевые слова: годограф, натуральный триэдр, теорема Вариньона, статические инварианты, контактные силы, экипаж наземного транспорта

Рекомендовано до публікації докт. техн. наук B. I. Самусею. Дата надходження рукопису 14.02.18. 